\title{
Eosinophils to Nucleated Cells Ratio Measurement
}

National Cancer Institute

\section{Source}

National Cancer Institute. Eosinophils to Nucleated Cells Ratio Measurement. NCI

Thesaurus. Code C150840.

The determination of the ratio of eosinophils compared to nucleated cells present in a sample. The measurement may be expressed as a ratio or percentage. 